\title{
Synthesis, Cytotoxicities and DNA-Binding Affinities of Benzofuran-3-ols and Their Fused Analogs
}

\author{
Zhong-Zhen Zhou, ${ }^{a, \#}$ Min Zou, ${ }^{a, \#}$ Jia Zhou ${ }^{a}{ }^{\circ}$ Chun-Qiong Zhou, ${ }^{a}$ Yan-Hong Deng, ${ }^{a}$ Ming-Hui Chen, ${ }^{a}$ \\ Chun-Ping Gu, ${ }^{a}$ Zhi-Hong JiAnG, ${ }^{a, b}$ Wen-Hua Chen, ${ }^{*, a}$ and Shu-Wen LiU*,a \\ ${ }^{a}$ School of Pharmaceutical Sciences, Southern Medical University; Guangzhou 510515, China: and ${ }^{b}$ School of Chinese \\ Medicine, Hong Kong Baptist University; Kowloon Tong, Hong Kong, China.
}

Received March 28, 2011; accepted May 22, 2011; published online May 30, 2011

A series of benzofuropyrazoles $2 \mathrm{a}-\mathrm{i}$ were synthesized in $10-92 \%$ from the reaction of 2-aroylbenzofuran3-ols 1a-i with hydrazine hydrate, and screened for their antitumor activities toward four human solid tumor cell lines, including gastric carcinoma cells MKN45, hepatocellular carcinoma cells HepG2, breast cancer cells MCF-7, and lung cancer cells A549. The results indicated that both compounds $1 \mathrm{a}-\mathrm{i}$ and $2 \mathrm{a}-\mathrm{i}$ displayed moderate antitumor activities. Among them, compound 2e exhibited potent inhibitory activity toward all the four tumor cell lines. In addition, compounds $1 \mathrm{e}$ and $2 \mathrm{e}$ showed strong DNA-binding affinities, and induced an increase in the viscosity of calf-thymus DNA, suggesting that they might act as an intercalator.

Key words benzofuran; benzofuropyrazole; cytotoxicity; DNA binding

Some serious modern human diseases, such as human immunodeficiency virus (HIV), cancers and diabetes, are increasingly threatening the public health. Among them, cancers are definitely the scourge on human being. ${ }^{1}$ Therefore, finding novel, potent and selective antitumor agents has become one of the major goals in modern medicinal chemistry. From the viewpoint of the efficiency in new drug discovery, chemical modification of natural products that display multiple biological activities may be one viable approach. A typical example of this is the rational structural modification of the antibiotics netropsin and distamycin leading to the development of lexitropsins. ${ }^{2)}$

In this field, we have keenly become interested in benzofurans that are ubiquitous in nature and attractive heterocycles for new drug discovery. ${ }^{3,4)}$ It is reported that benzofurans exhibit a wide range of pharmacological activities, including antitumor and antiviral activities (e.g., naturally occurring cyclopenta[ $b]$ benzofurans), ${ }^{5)}$ potent, reversible and non-selective aromatase inhibitory effect (e.g., 1-[(benzofuran-2yl)phenylmethyl]imidazoles), ${ }^{6}$ and selective cytotoxicity against tumorigenic cell lines. ${ }^{7}$ Thus, it is anticipated that 2aroylbenzofuran-3-ols that we recently reported, ${ }^{8)}$ may display promising antitumor activities. On the other hand, many antitumor agents feature a pyrazolyl group as one of the main constituents. Such fused pyrazole-containing antitumor agents, for example, indenopyrazole derivatives, ${ }^{9}$ benzofuro[3,2-c]pyrazolyl-3-amine ${ }^{10,11)}$ and 3-phenylbenzofuropyrazoles, ${ }^{12)}$ show high antitumor activities. These observations, together with the combination principles of drug design, make us reasoning that incorporating of benzofurans with pyrazoles may lead to potent antitumor agents.

The primary objectives of the work reported in this paper, therefore, were two-folds. Firstly, we described the synthesis of fused pyrazole-containing 2-aroylbenzofurans, i.e. benzofuropyrazoles $\mathbf{2 a}-\mathbf{i}$, from 2-aroylbenzofuran-3-ols $\mathbf{1 a}-\mathbf{i}^{8)}$ (Chart 1), and assayed the antitumor activities of both compounds $1 \mathbf{a}-\mathbf{i}$ and $\mathbf{2} \mathbf{a}-\mathbf{i}$ toward four human tumor cells, including gastric carcinoma cells MKN45, hepatocellular carcinoma cells HepG2, breast cancer cells MCF-7, and lung cancer cells A549. In addition, to gain further insight into their biological activities, we investigated the DNA-binding affinities of compounds $1 \mathbf{e}$ and $2 \mathrm{e}$ by means of spectrophotometric titrations and viscosity measurements.

\section{Results and Discussion}

Synthesis of Benzofuropyrazoles $2 a-i$ Compounds 2a-i were prepared according to the reported protocols (Chart 1). ${ }^{13,14)}$ Thus, one-step reaction of compounds $1 \mathbf{a}-\mathbf{i}$ with hydrazine hydrate in refluxing acetic acid afforded compounds $2 \mathbf{a}-\mathbf{i}$ in $10-92 \%$. These compounds were fully characterized by MS (low resolution (LR) and high resolution (HR)) and NMR $\left({ }^{1} \mathrm{H}\right.$ and ${ }^{13} \mathrm{C}$ ) (see Experimental). They afforded mass spectra with the $\mathrm{m} / \mathrm{z}$ values corresponding to $[\mathrm{M}+\mathrm{H}]^{+}$. Their NMR spectra were in full agreement with the given structures. The purity of each compound was judged from its clean NMR and one spot on TLC developed by different eluting solvents.

Biological Activities of Compounds $\mathbf{2 a}-\mathbf{i}$ The in vitro antitumor activities of compounds $\mathbf{1} \mathbf{a}-\mathbf{i}$ and $\mathbf{2 a}-\mathbf{i}$ against the four cancer cell lines MKN45, HepG2, MCF-7 and A549, were screened by a cell proliferation assay using 3(4,5-dimethyl thiazol-2-yl)-2,5-diphenyl tetrazolium bromide (MTT). ${ }^{15)}$ Their inhibition percentages at the concentration of $100 \mu \mathrm{M}$ are shown in Fig. 1.

As can be seen from Fig. 1, most of compounds $\mathbf{2 a}-\mathbf{i}$ exhibited moderate antiproliferative activities, in particular toward HepG2, MCF-7 and A549 cells. In contrast, most of compounds $1 \mathbf{a}-\mathbf{i}$ were active in inhibiting MKN45, but weak toward the other three cells. Among them, compound 2e showed strong inhibition toward all the four tumor cells. Further analysis on the structure-activity correlations indicates that compounds $\mathbf{2 e}-\mathbf{h}$ bearing methoxy groups at ring A were more active than or comparable to their corresponding compounds $\mathbf{2 a}-\mathbf{d}$ without methoxy groups, suggesting that methoxy group plays a crucial role in modulating the inhibitory activity. However, the presence of a methoxy group at ring B led to a decrease in the activity, that is, compounds $\mathbf{2 b}$ and $\mathbf{f}$ that were methoxylated at ring $\mathrm{B}$ were much less ac- 




$1 \mathbf{a}-\mathbf{i}$

$2 a-\mathbf{i}$

\begin{tabular}{lllllll}
\hline Compound & $\mathrm{R}^{1}$ & $\mathrm{R}^{2}$ & Compound & $\mathrm{R}^{1}$ & $\mathrm{R}^{2}$ & Yield (\%) \\
\hline $\mathbf{1 a}$ & $\mathrm{H}$ & $\mathrm{H}$ & $\mathbf{2 a}$ & $\mathrm{H}$ & $\mathrm{H}$ & 92 \\
$\mathbf{1 b}$ & $\mathrm{H}$ & $\mathrm{MeO}$ & $\mathbf{2 b}$ & $\mathrm{H}$ & $\mathrm{MeO}$ & 80 \\
$\mathbf{1 c}$ & $\mathrm{H}$ & $\mathrm{Me}$ & $\mathbf{2 c}$ & $\mathrm{H}$ & $\mathrm{Me}$ & 84 \\
$\mathbf{1 d}$ & $\mathrm{H}$ & $\mathrm{Cl}$ & $\mathbf{2 d}$ & $\mathrm{H}$ & $\mathrm{Cl}$ & 68 \\
$\mathbf{1 e}$ & $5-\mathrm{MeO}$ & $\mathrm{H}$ & $\mathbf{2 e}$ & $7^{\prime}-\mathrm{MeO}$ & $\mathrm{H}$ & 88 \\
$\mathbf{1 f}$ & $5-\mathrm{MeO}$ & $\mathrm{MeO}$ & $\mathbf{2 f}$ & $7^{\prime}-\mathrm{MeO}$ & $\mathrm{MeO}$ & 82 \\
$\mathbf{1 g}$ & $5-\mathrm{MeO}$ & $\mathrm{Me}$ & $\mathbf{2 g}$ & $7^{\prime}-\mathrm{MeO}$ & $\mathrm{Me}$ & 89 \\
$\mathbf{1 h}$ & $5-\mathrm{MeO}$ & $\mathrm{Cl}$ & $\mathbf{2 h}$ & $7^{\prime}-\mathrm{MeO}^{2} \mathrm{Cl}$ & 87 \\
$\mathbf{1 i}$ & $7-\mathrm{NO}_{2}$ & $\mathrm{Me}$ & $\mathbf{2 i}$ & $5^{\prime}-\mathrm{NO}_{2}$ & $\mathrm{Me}$ & 10
\end{tabular}

Chart 1. Synthetic Route for Compounds $\mathbf{2 a}-\mathbf{i}$
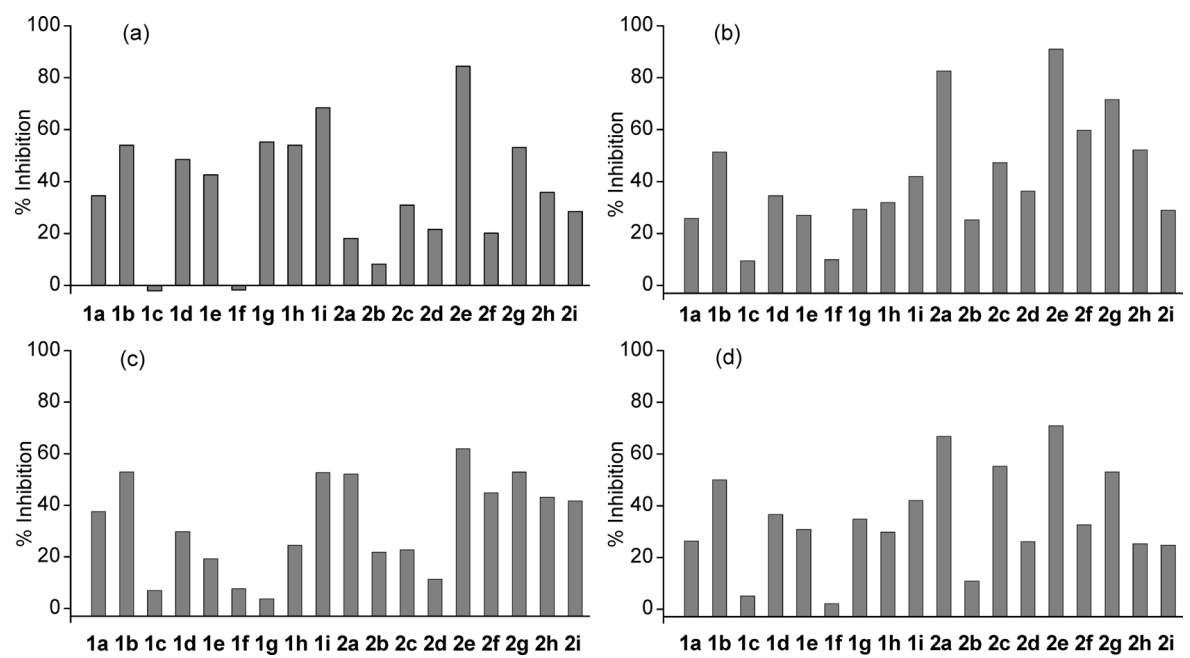

Fig. 1. Antiproliferative Activities of Compounds 1a-i and 2a-i (100 $\mu \mathrm{M}$ ) toward MKN45 (a), HepG2 (b), MCF-7 (c), and A549 (d) Cells after $48 \mathrm{~h}$ Incubation

tive than their corresponding compounds $\mathbf{2 a}$ and $\mathbf{e}$ that were not methoxylated at ring B, respectively. No clear structureactivity relationship was found in the other substituents.

To better understand their pharmacological activities, we measured the cytotoxicity $\mathrm{IC}_{50}$ values of the compounds that showed strong inhibition, together with those of their corresponding derivatives/precursors for comparison, that is, compounds $(\mathbf{1}-\mathbf{2}) \mathbf{a},(\mathbf{1}-\mathbf{2}) \mathbf{b},(\mathbf{1}-\mathbf{2}) \mathbf{e}$, and $(\mathbf{1}-\mathbf{2}) \mathbf{i}$ (Table 1). Here, the $\mathrm{IC}_{50}$ value represents the concentration of one compound resulting in a $50 \%$ inhibition in cell growth after $48 \mathrm{~h}$ incubation, and was the mean value of three repeated experiments. Doxorubicin was used as a positive control.

It can be seen that compound $2 \mathbf{e}$ was the most active in inhibiting MKN45 and HepG2 with the $\mathrm{IC}_{50}$ values being $39 \pm 3$ $\mu \mathrm{M}$ and $34 \pm 2 \mu \mathrm{M}$, respectively. Compound $2 \mathrm{a}\left(\mathrm{IC}_{50}=32 \pm 7\right.$ $\mu \mathrm{M})$ was similar with compound $\mathbf{2 e}$ in inhibiting HepG2. Under our assay conditions, no compound was active toward MCF-7 Cells. Compounds $\mathbf{1 i}$ and $\mathbf{2 e}$ were similar in inhibiting A549. The fact that compound $2 \mathrm{e}$ was slightly more potent than doxorubicin in inhibiting MCF-7 and exhibited high in- hibitory activity toward all the four tumor cell lines, suggests that it may be exploitable as a lead compound for further structural optimization in search for potent antitumor agents.

Table 1. Antiproliferative Activities of Compounds $(\mathbf{1}-\mathbf{2}) \mathbf{a},(\mathbf{1}-\mathbf{2}) \mathbf{b}$, $(\mathbf{1}-\mathbf{2}) \mathbf{e}$, and $(\mathbf{1}-\mathbf{2}) \mathbf{i}$

\begin{tabular}{ccccc}
\hline \hline \multirow{2}{*}{ Compound } & \multicolumn{4}{c}{ Cytotoxicity $\mathrm{IC}_{50}(\text { Mean } \pm \text { S.D., } \mu \mathrm{M})^{a)}$} \\
\cline { 2 - 5 } & MKN45 & HepG2 & MCF-7 & A549 \\
\hline $\mathbf{1 a}$ & $>100$ & $>100$ & $>100$ & $>100$ \\
$\mathbf{1 b}$ & $>100$ & $134 \pm 14$ & $>100$ & $>100$ \\
$\mathbf{1 e}$ & $70 \pm 10$ & $>100$ & $>100$ & $>100$ \\
$\mathbf{1 i}$ & $>100$ & $>100$ & $>100$ & $42 \pm 2$ \\
$\mathbf{2 a}$ & $>100$ & $32 \pm 7$ & $>100$ & $>100$ \\
$\mathbf{2 b}$ & $>100$ & $>100$ & $>100$ & $>100$ \\
$\mathbf{2} \mathbf{e}$ & $39 \pm 3$ & $34 \pm 2$ & $112 \pm 7$ & $90 \pm 11$ \\
$\mathbf{2 i}$ & $>100$ & $>100$ & $>100$ & $>100$ \\
Doxorubicin & $1.1 \pm 0.3$ & $3.0 \pm 0.4$ & $232 \pm 28$ & $3.5 \pm 0.1$ \\
\hline
\end{tabular}

a) $\mathrm{The}_{\mathrm{IC}}$ values of all the other compounds that were not listed, were estimated to be greater than $100 \mu \mathrm{M}$. 

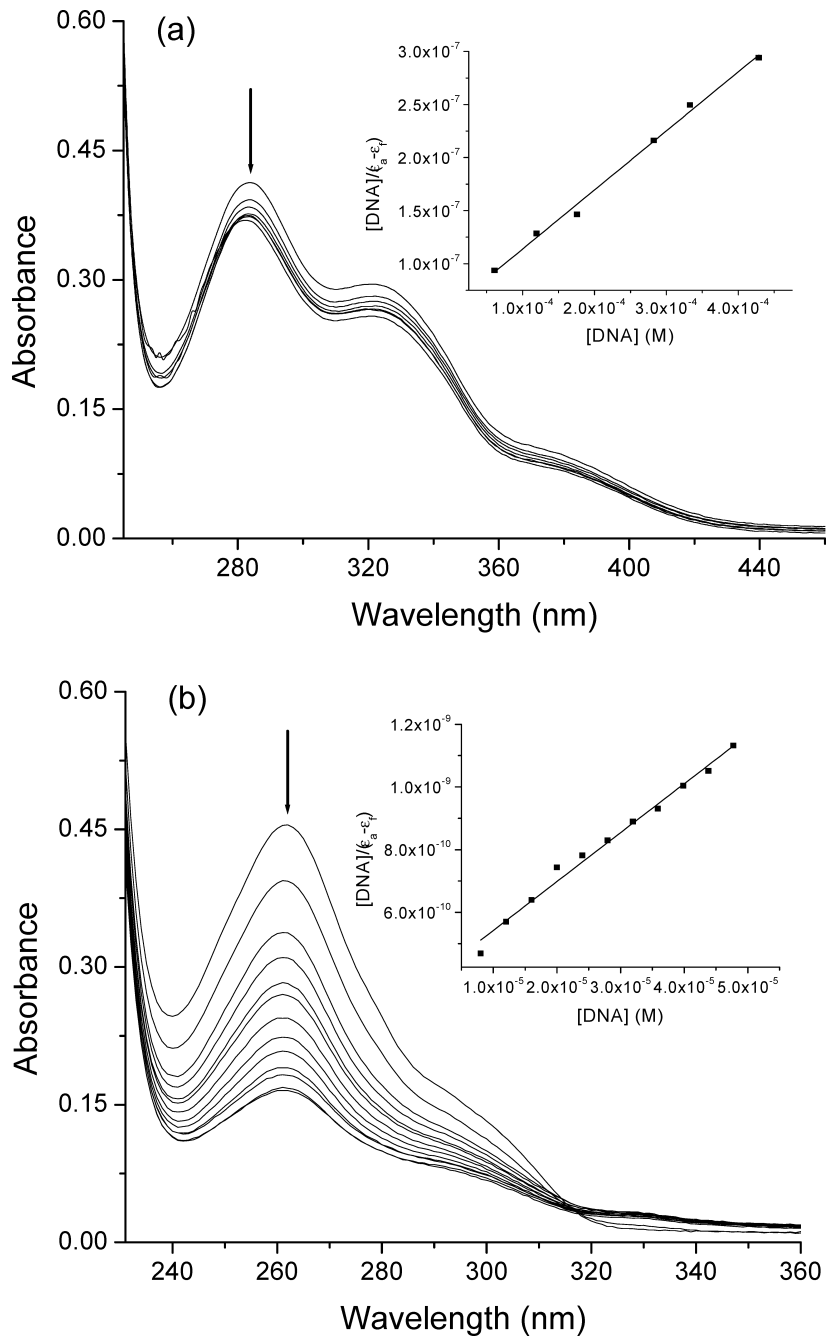

Fig. 2. Spectrophotometric Titrations of (a) 1 e $\left(3.0 \times 10^{-5} \mathrm{M}\right)$ and (b) $2 \mathrm{e}$ $\left(6.8 \times 10^{-6} \mathrm{M}\right)$ with CT DNA of Increasing Concentrations $\left(0-4.3 \times 10^{-4} \mathrm{M}\right.$ for 1e; $0-4.4 \times 10^{-5} \mathrm{M}$ for $\left.2 \mathrm{e}\right)$ in $5 \mathrm{~mm}$ Tris- $\mathrm{HCl}$ Buffer $(5 \mathrm{~mm} \mathrm{NaCl}, \mathrm{pH}$ 7.0) at Room Temperature

The arrows indicate the absorbance changes upon increasing DNA concentration. The insets are the plots of [DNA] $/\left(\varepsilon_{\mathrm{a}}-\varepsilon_{\mathrm{f}}\right) v s$. [DNA].

The aforementioned results may be rationalized by taking into consideration the structures of compounds $\mathbf{1 a}-\mathbf{i}$ and 2a-i. It is known that hydrogen bonding is one factor that plays a crucial role in inhibitory activities of this class of compounds. ${ }^{16,17)}$ Thus, we believe that the moderate antitumor activities of compounds $\mathbf{1} \mathbf{a}-\mathbf{i}$ and $\mathbf{2} \mathbf{a}-\mathbf{i}$ were, at least in part due to their abilities to form hydrogen-bonding. This was supported by our preliminary study that, under our assay conditions $(100 \mu \mathrm{M})$, bridging compound $\mathbf{2 a}$ at the $\mathrm{NH}$ group with $n$-propyl chain to form dimeric $\mathbf{2 a}$, led to a complete loss of the anti-proliferative activity toward MKN45, MCF-7 and A549 cells, and a decrease from 83 to $47 \%$ inhibition toward HepG2 cells. In addition, the methoxy group on the ring $\mathrm{A}$ as a hydrogen bonding acceptor may make further contribution to the enhanced activity of compound $2 \mathbf{e}$.

DNA Binding of Compounds 1e and 2e To gain further insight into the biological activities of benzofuropyrazole $2 \mathbf{e}$ and its precursor 1e, we investigated their interaction with calf thymus (CT) DNA, by means of spectrophotometric titrations and viscosity measurement.

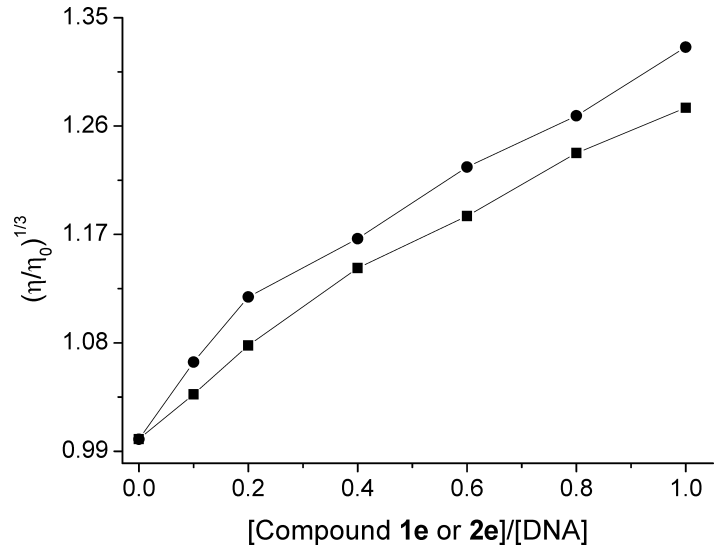

Fig. 3. Effect of Increasing Amounts of Compounds 1e ( $\mathbf{\square})$ and $\mathbf{2 e}(\mathbf{O})$ on the Relative Viscosity of CT DNA $\left(1.0 \times 10^{-4} \mathrm{M}\right)$ in $5 \mathrm{~mm}$ Tris- $\mathrm{HCl}$ Buffer $(5 \mathrm{~mm} \mathrm{NaCl}, \mathrm{pH} 7.0)$ at $20^{\circ} \mathrm{C}$

As shown in Fig. 2, compound 1e showed a UV-Vis absorption spectrum with a strong $\pi-\pi^{*}$ transition band at $\lambda_{\max }=282 \mathrm{~nm}$ and a moderate $n-\pi^{*}$ transition band at $\lambda_{\max }=$ $324 \mathrm{~nm}$, whereas compound $\mathbf{2 e}$ has a strong $\pi-\pi^{*}$ transition band at $\lambda_{\max }=261 \mathrm{~nm}$. Upon interacting with CT DNA, both compounds showed decreases in the molar absorptivity (hypochromism) and small red shifts in the wavelength (bathochromism), suggesting that they were capable of forming stable complexes with CT DNA. Their binding constants $K_{\mathrm{a}}$ 's were calculated from the ratio of the slope to the intercept in the plots of [DNA] $/\left(\varepsilon_{\mathrm{a}}-\varepsilon_{\mathrm{f}}\right) v s$. [DNA], according to Eq. $1,{ }^{18)}$ in which [DNA] is the concentration of CT DNA in base, $\varepsilon_{\mathrm{a}}, \varepsilon_{\mathrm{f}}$ and $\varepsilon_{\mathrm{b}}$ are the extinction coefficients corresponding to $A_{\text {obsd }}$ [compound], for the free and fully bound compounds, respectively. The $K_{\mathrm{a}}$ values of compounds $1 \mathrm{e}$ and $\mathbf{2 e}$ were found to be $(9.55 \pm 1.18) \times 10^{3} \mathrm{M}^{-1}$ and $(4.04 \pm 0.32) \times$ $10^{4} \mathrm{M}^{-1}$, respectively. Thus, compound 2e showed higher DNA-binding affinity than compound $\mathbf{1 e}$, in agreement with the fact that it exhibited higher anti-proliferative activities toward the four tumor cell lines. ${ }^{19)}$

$$
[\mathrm{DNA}]\left(\varepsilon_{\mathrm{a}}-\varepsilon_{\mathrm{f}}\right)=[\mathrm{DNA}] /\left(\varepsilon_{\mathrm{b}}-\varepsilon_{\mathrm{f}}\right)+1 / K_{\mathrm{a}}\left(\varepsilon_{\mathrm{b}}-\varepsilon_{\mathrm{f}}\right)
$$

Their DNA-binding activities were further studied by viscosity measurements. It is observed that the viscosity of CT DNA increased with increasing amounts of compounds $1 \mathbf{e}$ and 2e (Fig. 3). Such behavior is in accordance with intercalation, which increases the relative viscosity because of the lengthening of the DNA double helix resulting from intercalation. ${ }^{19)}$ Thus, these two compounds may intercalate between the adjacent base pairs of CT DNA, leading to an extension in the helix and an increase in the viscosity.

\section{Concluding Remarks}

In summary, a series of benzofuropyrazoles were synthesized and characterized with MS (LR and HR) and NMR $\left({ }^{1} \mathrm{H}\right.$ and ${ }^{13} \mathrm{C}$ ). Their antitumor activities were assayed against four human solid tumor cell lines MKN45, HepG2, MCF-7 and A549. The results indicated that both compounds $\mathbf{1 a}-\mathbf{i}$ and 2a-i displayed moderate antitumor activities. Among them, compound 2e, i.e. 7-methoxy-3-phenyl-1H-benzofuro[3,2c]pyrazole, was the most active in inhibiting all the four tumor cell lines. The structure-activity correlations high- 
lighted the facts that the ability to form hydrogen bonding, for example by pyrazole unit and methoxy group on the ring A, might play a crucial role in modulating inhibitory activity. In addition, compounds 1e and 2e were capable of forming stable complexes with CT DNA, possibly via an intercalative mode.

\section{Experimental}

General Electrospray ionization (ESI)-MS and HR-ESI-MS spectra were measured on Waters UPLC/Quattro Premier XE and Agilent 6460 Triple Quadrupole mass spectrometers, respectively. ${ }^{1} \mathrm{H}$ - and ${ }^{13} \mathrm{C}-\mathrm{NMR}$ spectra were recorded in DMSO- $d_{6}$ using Varian Mercury 400 spectrometers and TMS as an internal reference. UV-Vis absorption measurements were conducted by using a TU-1901 spectrophotometer (Purkinje Instrument Co. China) equipped with quartz cells. Viscosity experiments were carried out on an Ubbelohde viscometer. CT DNA was obtained from Sigma Chemical Co. (St. Louis, MO, U.S.A.), and its concentration was determined spectrophotometrically using the molar extinction coefficient of $6600 \mathrm{~mol}^{-1}$ $\mathrm{cm}^{-1} /$ base at $260 \mathrm{~nm}$. All the other reagents and chemicals were obtained from commercial sources and used as received unless otherwise stated.

Synthesis of Compounds 2a-i. General Procedures Hydrazine hydrate $(0.65 \mathrm{~g}, 10 \mathrm{mmol})$ was added to a solution of $1 \mathbf{a}-\mathbf{i}(5.0 \mathrm{mmol})$ in acetic acid $(25 \mathrm{ml})$ and the resulting mixture was refluxed for $24 \mathrm{~h}$. Acetic acid was removed in vacuum and the obtained residue was purified by chromatography on a silica-gel column (petroleum ether/acetone, 10/1 by volume) to give compounds $\mathbf{2} \mathbf{a}-\mathbf{i}$.

3-Phenyl-1 $H$-benzofuro[3,2-c]pyrazole 2a: (92\%) having ${ }^{1} \mathrm{H}-\mathrm{NMR}(400$ MHz, DMSO- $\left.d_{6}\right) \delta: 7.38-7.42\left(\mathrm{~m}, 2 \mathrm{H}, \mathrm{H}-6^{\prime}, \mathrm{H}-8^{\prime}\right), 7.50(\mathrm{t}, J=7.8 \mathrm{~Hz}, 1 \mathrm{H}$, H-7'), 7.56-7.95 (m, $6 \mathrm{H}, \mathrm{Ar}-\mathrm{H}), 13.38$ (s, $1 \mathrm{H}, \mathrm{NH}) .{ }^{13} \mathrm{C}-\mathrm{NMR}(100 \mathrm{MHz}$, DMSO- $\left.d_{6}\right) \delta: 112.9\left(\mathrm{C}-11^{\prime}\right), 119.3,120.4,123.3\left(\mathrm{C}-8^{\prime}\right), 125.1,126.0,126.9$, 127.7, 128.9, 129.2, 131.4 (C-12'), 143.9 (C-3'), 162.38 (C-10'). ESI-MS $m / z: 234.78\left([\mathrm{M}+\mathrm{H}]^{+}\right)$. HR-ESI-MS for $\mathrm{C}_{15} \mathrm{H}_{11} \mathrm{~N}_{2} \mathrm{O}\left([\mathrm{M}+\mathrm{H}]^{+}\right)$Calcd: 235.0871; Found: 235.0844.

3-(4-Methoxyphenyl)-1 $H$-benzofuro[3,2-c]pyrazole $2 \mathbf{b}$ : $(80 \%)$ having ${ }^{1} \mathrm{H}-$ NMR $\left(400 \mathrm{MHz}, \mathrm{DMSO}-d_{6}\right) \delta: 3.82(\mathrm{~s}, 3 \mathrm{H}, \mathrm{MeO}), 7.13(\mathrm{~d}, J=7.6 \mathrm{~Hz}, 2 \mathrm{H}$, H-17', H-15'), 7.38 (t, J=7.2 Hz, 1H, H-6'), 7.47 (t, $J=7.2 \mathrm{~Hz}, 1 \mathrm{H}, \mathrm{H}-7^{\prime}$ ), $7.71-7.91(\mathrm{~m}, 4 \mathrm{H}, \mathrm{Ar}-\mathrm{H}), 13.38(\mathrm{~s}, 1 \mathrm{H}, \mathrm{NH}) .{ }^{13} \mathrm{C}-\mathrm{NMR}(100 \mathrm{MHz}$, DMSO- $\left.d_{6}\right) \delta: 55.2(\mathrm{MeO}), 113.0,113.7,114.6,119.9\left(\mathrm{C}-9^{\prime}\right), 120.0\left(\mathrm{C}-8^{\prime}\right)$, 126.3, 126.4, 131.1 (C-15', C-17'), $143.7\left(\mathrm{C}-3^{\prime}\right), 158.8\left(\mathrm{C}-10^{\prime}\right), 161.9$ (C$\left.16^{\prime}\right)$. ESI-MS $m / z$ : $264.84\left([\mathrm{M}+\mathrm{H}]^{+}\right)$. HR-ESI-MS for $\mathrm{C}_{16} \mathrm{H}_{13} \mathrm{~N}_{2} \mathrm{O}_{2}$ $\left([\mathrm{M}+\mathrm{H}]^{+}\right)$Calcd: 265.0977; Found: 265.0940 .

3-p-Tolyl-1 $H$-benzofuro[3,2-c]pyrazole 2c: (84\%) having ${ }^{1} \mathrm{H}-\mathrm{NMR}$ $\left.\left(400 \mathrm{MHz}, \mathrm{DMSO}-d_{6}\right) \delta: 2.36(\mathrm{~s}, 3 \mathrm{H}, \mathrm{Me}), 7.36-7.38(\mathrm{~m}, 3 \mathrm{H}, \mathrm{Ar}-\mathrm{H})\right), 7.48$ $\left(\mathrm{t}, J=7.6 \mathrm{~Hz}, 1 \mathrm{H}, \mathrm{H}-7^{\prime}\right), 7.69-7.95(\mathrm{~m}, 4 \mathrm{H}, \mathrm{Ar}-\mathrm{H}), 13.26(\mathrm{~s}, 1 \mathrm{H}, \mathrm{NH}) .{ }^{13} \mathrm{C}-$ NMR (100 MHz, DMSO- $\left.d_{6}\right) \delta$ : $20.8(\mathrm{Me}), 98.3\left(\mathrm{C}-11^{\prime}\right), 123.3\left(\mathrm{C}-5^{\prime}\right), 124.9$ (C-9') 125.1, 126.0, 126.8, 127.7 (C-13'), 128.9, 129.2, 129.7, 137.3 (C$\left.12^{\prime}\right), 143.8\left(\mathrm{C}-3^{\prime}\right), 162.3\left(\mathrm{C}-10^{\prime}\right)$. ESI-MS $m / z: 248.70\left([\mathrm{M}+\mathrm{H}]^{+}\right)$. HR-ESIMS for $\mathrm{C}_{16} \mathrm{H}_{13} \mathrm{~N}_{2} \mathrm{O}\left([\mathrm{M}+\mathrm{H}]^{+}\right)$Calcd: 249.1028; Found: 249.1002 .

3-(4-Chlorophenyl)-1H-benzofuro[3,2-c]pyrazole 2d: (68\%) having ${ }^{1} \mathrm{H}$ NMR $\left(400 \mathrm{MHz}\right.$, DMSO- $\left.d_{6}\right) \delta: 7.37-7.43\left(\mathrm{~m}, 1 \mathrm{H}, \mathrm{H}-6^{\prime}\right), 7.46-7.51(\mathrm{~m}$, $\left.1 \mathrm{H}, \mathrm{H}-7^{\prime}\right), 7.58\left(\mathrm{~d}, J=8.4 \mathrm{~Hz}, 1 \mathrm{H}, \mathrm{H}-8^{\prime}\right), 7.64\left(\mathrm{~d}, J=8.4 \mathrm{~Hz}, 1 \mathrm{H}, \mathrm{H}-5^{\prime}\right)$, $7.72-7.83$ (m, 2H, H-17', H-15'), 7.90-7.99 (m, 2H, H-14', H-18'), 13.43 $(\mathrm{s}, 1 \mathrm{H}, \mathrm{NH}) .{ }^{13} \mathrm{C}-\mathrm{NMR}\left(100 \mathrm{MHz}, \mathrm{DMSO}-d_{6}\right) \delta: 112.9,113.3,116.1\left(\mathrm{C}-9^{\prime}\right)$, 119.4, 120.5, 123.4 (C-6'), 126.7 (C-13'), 129.0, 129.3, 130.2 (C-16'), 144.0 $\left(\mathrm{C}-12^{\prime}\right), 145.2\left(\mathrm{C}-3^{\prime}\right), 161.5\left(\mathrm{C}-10^{\prime}\right)$. ESI-MS $m / z: 268.70\left([\mathrm{M}]^{+}\right)$. HR-ESIMS for $\mathrm{C}_{15} \mathrm{H}_{10} \mathrm{ClN}_{2} \mathrm{O}\left([\mathrm{M}+\mathrm{H}]^{+}\right)$Calcd: 269.0482; Found: 269.0442 .

7-Methoxy-3-phenyl-1H-benzofuro[3,2-c]pyrazole 2e: (88\%) having ${ }^{1} \mathrm{H}$ NMR $\left(400 \mathrm{MHz}, \mathrm{DMSO}-d_{6}\right) \delta: 3.86(\mathrm{~s}, 3 \mathrm{H}, \mathrm{MeO}), 6.96-7.01(\mathrm{~m}, 1 \mathrm{H}, \mathrm{H}-$ $\left.6^{\prime}\right), 7.33-7.40\left(\mathrm{~m}, 2 \mathrm{H}, \mathrm{H}-5^{\prime}\right.$ and $\left.\mathrm{H}-8^{\prime}\right), 7.50-7.58\left(\mathrm{~m}, 2 \mathrm{H}, \mathrm{H}-15^{\prime}, \mathrm{H}-17^{\prime}\right)$, 7.67-7.95 (m, 3H, Ar-H), 13.15 (s, 1H, NH). ${ }^{13} \mathrm{C}-\mathrm{NMR}(100 \mathrm{MHz}$, DMSO$\left.d_{6}\right) \delta: 55.6(\mathrm{MeO}), 98.5\left(\mathrm{C}-11^{\prime}\right), 112.9\left(\mathrm{C}-5^{\prime}\right), 120.4\left(\mathrm{C}-9^{\prime}\right), 123.3\left(\mathrm{C}-8^{\prime}\right)$, $124.6\left(\mathrm{C}-12^{\prime}\right), 126.8,127.6,128.9,129.5,137.2\left(\mathrm{C}-16^{\prime}\right), 142.7\left(\mathrm{C}-3^{\prime}\right), 150.4$ $\left(\mathrm{C}-10^{\prime}\right), 162.3\left(\mathrm{C}-7^{\prime}\right)$. ESI-MS m/z: $265.09\left([\mathrm{M}+\mathrm{H}]^{+}\right), 287.07\left([\mathrm{M}+\mathrm{Na}]^{+}\right)$. HR-ESI-MS for $\mathrm{C}_{16} \mathrm{H}_{13} \mathrm{~N}_{2} \mathrm{O}_{2}\left([\mathrm{M}+\mathrm{H}]^{+}\right)$Calcd: 265.0977; Found: 265.0939.

7-Methoxy-3-(4-methoxyphenyl)-1H-benzofuro[3,2-c]pyrazole 2f: (82\%) having ${ }^{1} \mathrm{H}-\mathrm{NMR}\left(400 \mathrm{MHz}, \mathrm{DMSO}-d_{6}\right) \delta: 3.82(\mathrm{~s}, 3 \mathrm{H}, \mathrm{MeO}), 3.86(\mathrm{~s}, 3 \mathrm{H}$, $\mathrm{MeO}), 6.95$ (d, $\left.J=8.0 \mathrm{~Hz}, 1 \mathrm{H}, \mathrm{H}-6^{\prime}\right), 7.12$ (d, $\left.J=8.6 \mathrm{~Hz}, 2 \mathrm{H}, \mathrm{H}-17^{\prime}, \mathrm{H}-15^{\prime}\right)$, 7.32-7.37 (m, 1H, H-5'), 7.66-7.88 (m, 3H, H-8', H-14', H-18'), 13.15 $(\mathrm{s}, 1 \mathrm{H}, \mathrm{NH}) .{ }^{13} \mathrm{C}-\mathrm{NMR}\left(100 \mathrm{MHz}, \mathrm{DMSO}-d_{6}\right) \delta: 55.1(\mathrm{MeO}), 55.6(\mathrm{MeO})$, $98.5\left(\mathrm{C}-11^{\prime}\right), 110.8\left(\mathrm{C}-8^{\prime}\right), 120.3,120.5,120.6,121.4,126.1\left(\mathrm{C}-13^{\prime}\right), 139.4$, 140.1, $142.3\left(\mathrm{C}-10^{\prime}\right), 158.8\left(\mathrm{C}-7^{\prime}\right), 163.7\left(\mathrm{C}-16^{\prime}\right)$. ESI-MS m/z: 295.11 $\left([\mathrm{M}+\mathrm{H}]^{+}\right), 317.14\left([\mathrm{M}+\mathrm{Na}]^{+}\right)$. HR-ESI-MS for $\mathrm{C}_{17} \mathrm{H}_{15} \mathrm{~N}_{2} \mathrm{O}_{3}\left([\mathrm{M}+\mathrm{H}]^{+}\right)$ Calcd: 295.1083; Found: 295.1041.
7-Methoxy-3-p-tolyl-1 $H$-benzofuro[3,2-c]pyrazole 2g: (89\%) having ${ }^{1} \mathrm{H}$ NMR (400 MHz, DMSO- $\left.d_{6}\right) \delta: 2.36(\mathrm{~s}, 3 \mathrm{H}, \mathrm{Me}), 3.86(\mathrm{~s}, 3 \mathrm{H}, \mathrm{MeO}), 6.96-$ 7.00 (m, 1H, H-6'), 7.33-7.37 (m, 3H, Ar-H)), 7.37-7.86 (m, 3H, Ar-H), $13.08(\mathrm{~s}, 1 \mathrm{H}, \mathrm{NH}) .{ }^{13} \mathrm{C}-\mathrm{NMR}\left(100 \mathrm{MHz}, \mathrm{DMSO}-d_{6}\right) \delta: 20.8(\mathrm{Me}), 55.6$ $(\mathrm{MeO}), 98.5\left(\mathrm{C}-11^{\prime}\right), 110.7\left(\mathrm{C}-8^{\prime}\right), 112.1\left(\mathrm{C}-5^{\prime}\right), 119.5,120.6,124.5(\mathrm{C}-$ 13'), 128.7, 129.4, 130.8, 136.9 (C-3', C-16'), 143.8 (C-10'), 158.4 (C-7'). ESI-MS $m / z: 279.07\left([\mathrm{M}+\mathrm{H}]^{+}\right), 301.12\left([\mathrm{M}+\mathrm{Na}]^{+}\right)$. HR-ESI-MS for $\mathrm{C}_{17} \mathrm{H}_{15} \mathrm{~N}_{2} \mathrm{O}_{2}\left([\mathrm{M}+\mathrm{H}]^{+}\right)$Calcd: 279.1134; Found: 279.1091.

3-(4-Chlorophenyl)-7-methoxy-1H-benzofuro[3,2-c]pyrazole $\mathbf{2 h}$ : $(87 \%)$ having ${ }^{1} \mathrm{H}-\mathrm{NMR}\left(400 \mathrm{MHz}, \mathrm{DMSO}-d_{6}\right) \delta: 3.86(\mathrm{~s}, 3 \mathrm{H}, \mathrm{MeO}), 6.96-7.02$ (m, 1H, H-6') 7.34 (d, $\left.J=13.2 \mathrm{~Hz}, 1 \mathrm{H}, \mathrm{H}-5^{\prime}\right), 7.60-7.93$ (m, 5H, Ar-H), $13.24(\mathrm{~s}, 1 \mathrm{H}, \mathrm{NH}) .{ }^{13} \mathrm{C}-\mathrm{NMR}\left(100 \mathrm{MHz}, \mathrm{DMSO}-d_{6}\right) \delta: 55.6(\mathrm{MeO}), 98.5$ $\left(\mathrm{C}-11^{\prime}\right), 110.6,111.0,120.0,120.1,126.4,129.1$ (C-16'), 131.9 (C-3'),

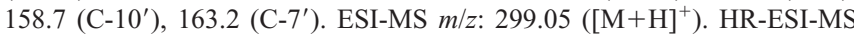
for $\mathrm{C}_{16} \mathrm{H}_{12} \mathrm{ClN}_{2} \mathrm{O}_{2}\left([\mathrm{M}+\mathrm{H}]^{+}\right)$Calcd: 299.0587; Found: 299.0541

5-Nitro-3-p-tolyl- $1 H$-benzofuro[3,2-c]pyrazole 2i: (10\%) having ${ }^{1} \mathrm{H}-\mathrm{NMR}$ $\left(400 \mathrm{MHz}, \mathrm{DMSO}-d_{6}\right) \delta: 2.37(\mathrm{~s}, 3 \mathrm{H}, \mathrm{Me}), 7.38-7.39(\mathrm{~m}, 2 \mathrm{H}, \mathrm{Ar}-\mathrm{H})$, 7.58-7.59 (m, 1H, Ar-H), 7.78-7.85 (m, 2H, Ar-H), 8.21-8.37 (m, $2 \mathrm{H}$, $\mathrm{Ar}-\mathrm{H}), 13.48(\mathrm{~s}, 1 \mathrm{H}, \mathrm{NH}) .{ }^{13} \mathrm{C}-\mathrm{NMR}\left(100 \mathrm{MHz}, \mathrm{DMSO}-d_{6}\right) \delta: 20.8(\mathrm{Me})$, $98.5\left(\mathrm{C}-11^{\prime}\right), 122.2,123.4,124.8$ (C-6') $126.8,129.7,134.1\left(\mathrm{C}-5^{\prime}\right), 137.6$, 137.7, $153.7\left(\mathrm{C}-10^{\prime}\right)$. ESI-MS $m / z: 294.01\left([\mathrm{M}+\mathrm{H}]^{+}\right)$. HR-ESI-MS for $\mathrm{C}_{16} \mathrm{H}_{12} \mathrm{~N}_{3} \mathrm{O}_{3}\left([\mathrm{M}+\mathrm{H}]^{+}\right)$Calcd: 294.0879; Found: 294.0849.

Biological Measurements. Cell Culture MKN45, HepG2 and MCF-7 cells were cultured in Dulbecco's modified Eagle's medium (DMEM) with $10 \%$ fetal bovine serum (FBS), whereas A549 cells were cultured in 1640 with $10 \%$ FBS. Cells were passaged at $70-80 \%$ confluence, about twice a week by trypsinization.

Cell Proliferation Assay Cell proliferation was determined using an MTT assay. ${ }^{15}$ Exponentially growing cells were plated in 96-well plates (16000 cells/well for MKN45 and MCF-7 cells, 10000 cells/well for HepG2 cells and 18000 cells/well for A549 cells) and incubated at $37^{\circ} \mathrm{C}$ for $24 \mathrm{~h}$ for attachment. Test compounds were prepared by dissolving in dimethyl sulfoxide (DMSO) at $100 \mathrm{~mm}$ and diluted with the medium. Then, culture medium was changed, and cells grew in medium with the test compounds. DMSO $(0.1 \%)$ was used as negative control. Cells were incubated at $37^{\circ} \mathrm{C}$ for $48 \mathrm{~h}$. Then the medium was replaced with MTT solution $(5 \mathrm{mg} / \mathrm{ml}, 100 \mu \mathrm{l})$ followed by incubation for another $3 \mathrm{~h}$. The medium was then aspirated and formazan crystals were dissolved in DMSO $(100 \mu \mathrm{l})$ for about $10 \mathrm{~min}$. The absorbance at $570 \mathrm{~nm}$ (Abs) of the suspension was measured by an enzymelinked immunosorbent assay (ELISA) reader. The inhibition percentage was calculated using the following formula: \% inhibition $=\left(\mathrm{Abs}_{\mathrm{control}}-\right.$ $\left.\mathrm{Abs}_{\text {compound }}\right) / \mathrm{Abs}_{\text {control }} \times 100 \%$.

The $\mathrm{IC}_{50}$ values of the test compounds and doxorubicin were measured by treating cells with drugs of varying concentrations, and analyzing by use of the prism statistical package (GraphPad Software, San Diego, CA, U.S.A.).

DNA-Binding Study. Spectrophotometric Titrations Spectrophotometric titrations were performed at room temperature by fixing the concentrations of compounds $\mathbf{1 e}$ and $\mathbf{2 e}$, while gradually increasing the concentration of CT DNA. ${ }^{20)}$ Typically, to a solution of $1 \mathrm{e}\left(3.0 \times 10^{-5} \mathrm{M}\right)$ in $5 \mathrm{~mm}$ Tris- $\mathrm{HCl}$ buffer $(5 \mathrm{~mm} \mathrm{NaCl}, \mathrm{pH} 7.0)$ were added aliquots of CT DNA $\left(3.1 \times 10^{-3} \mathrm{M}\right)$ solution containing $1 \mathrm{e}\left(3.0 \times 10^{-5} \mathrm{M}\right)$ in $5 \mathrm{~mm}$ Tris- $\mathrm{HCl}$ buffer ( $5 \mathrm{~mm} \mathrm{NaCl}, \mathrm{pH}$ 7.0). The mixing was achieved by stirring for $2 \mathrm{~min}$. Then, the corresponding absorption spectra were measured. The operations repeated until saturation reached. The spectrophotometric titrations of $2 \mathrm{e}$ were conducted in a similar way.

Viscosity Measurements Viscosity experiments were carried out in $5 \mathrm{~mm}$ Tris- $\mathrm{HCl}$ buffer $(5 \mathrm{~mm} \mathrm{NaCl}, \mathrm{pH} 7.0)$ at $20^{\circ} \mathrm{C}$. Thus, the solution of compound $1 \mathrm{e}$ (or $2 \mathrm{e})\left(1.0 \times 10^{-5}-1.0 \times 10^{-4} \mathrm{M}\right)$ was added to the solution of CT DNA $\left(1.0 \times 10^{-4} \mathrm{M}\right)$. Flow time $(t)$ of each sample was measured three times, and the average flow time was calculated. Data were presented as $\left(\eta / \eta_{0}\right)^{1 / 3}$ versus the concentration ratios of compound $\mathbf{1 e}$ (or $\mathbf{2 e}$ ) to CT DNA, where $\eta$ is the relative viscosity of CT DNA in the presence of compound $1 \mathbf{e}$ (or $\mathbf{2 e}$ ), and $\eta_{0}$ is the relative viscosity of CT DNA alone. Relative viscosity was calculated according to $\eta=t-t_{0},{ }^{19)}$ where $t_{0}$ is the flow time of buffer solution.

Acknowledgment This work was financially supported by the Natural Science Foundation (9451051501002541) and the Department of Education of Guangdong Province, Southern Medical University and the National Natural Science Foundation of China (No. 21002048).

\footnotetext{
References and Notes

1) Henderson I. C., Curr. Prob. Cancer, 14, 165-230 (1990).

2) Lown J. W., Anticancer Drug Des., 3, 25-40 (1988).
} 
3) Ono M., Kawashima H., Nonaka A., Kawai T., Haratake M., Mori H., Kung M.-P., Kung H. F., Saji H., Nakayama M., J. Med. Chem., 49, $2725-2730$ (2006).

4) Atta S. M. S., Farrag D. S., Sweed A. M. K., Abdel-Rahman A. H., Eur. J. Med. Chem., 45, 4920-4927 (2010).

5) Kim S., Salim A. A., Swanson S. M., Kinghorn A. D., Anticancer Agents Med. Chem., 6, 319-345 (2006).

6) Whomsley R., Fernandez E., Nicholls P. J., Smith H. J., Lombardi P., Pestellini V., J. Steroid Biochem. Mol. Biol., 44, 675-676 (1993).

7) Hayakawa I., Shioya R., Agatsuma T., Furukawa H., Naruto S., Sugano Y., Bioorg. Med. Chem. Lett., 14, 455-458 (2004).

8) Zhou Z.-Z., Deng Y.-H., Jiang Z.-H., Chen W.-H., Adv. Synth. Catal., 352, 1909-1913 (2010).

9) Yue E. W., Higley C. A., DiMeo S. V., Carini D. J., Nugiel D. A., Benware C., Benfield P. A., Burton C. R., Cox S., Grafstrom R. H., Sharp D. M., Sisk L. M., Boylan J. F., Muckelbauer J. K., Smallwood A. M., Chen H. Y., Chang C. H., Seitz S. P., Trainor G. L., J. Med. Chem., 45, 5233-5248 (2002).

10) Talley J., Stephen R., WO Patent 96/09304 (1996) [Chem. Abstr., 125, 114605-114609 (1996)].

11) Caruso F. S., WO Patent 00/29023 (2000) [Chem. Abstr., 133, 91099113 (2000)].

12) Murata K., Kumagai H., Kawashima T., Tamitsu K., Irie M., Nakajima H., Suzu S., Shibuya M., Kamihira S., Nosaka T., Asano S., Kitamura T., J. Biol. Chem., 278, 32892-32898 (2003).
13) Moser W. A., Serridge P. M., Lipp D. W., J. Org. Chem., 37, 24022405 (1972).

14) Gatta F., Settimj G., J. Heterocycl. Chem., 21, 937—943 (1984).

15) Yu L., Wu W. K. K., Li Z. J., Liu Q. C., Li H. T., Wu Y. C., Cho C. H., Mol. Pharmacol., 75, 1364-1373 (2009).

16) Dinges J., Albert D. H., Arnold L. D., Ashworth K. L., AkritopoulouZanze I., Bousquet P. F., Bouska J. J., Cunha G. A., Davidsen S. K., Diaz G. J., Djuric S. W., Gasiecki A. F., Gintant G. A., Gracias V. J., Harris C. M., Houseman K. A., Hutchins C. W., Johnson E. F., Li H., Marcotte P. A., Martin R. L., Michaelides M. R., Nyein M., Sowin T. J., Su Z., Tapang P. H., Xia Z., Zhang H. Q., J. Med. Chem., 50, 2011-2029 (2007)

17) Yue E. W., Higley C. A., DiMeo S. V., Carini D. J., Nugiel D. A., Benware C., Benfield P. A., Burton C. R., Cox S., Grafstrom R. H., Sharp D. M., Sisk L. M., Boylan J. F., Muckelbauer J. K., Smallwood A. M., Chen H., Chang C.-H., Seitz S. P., Trainor G. L., J. Med. Chem., 45, $5233-5248$ (2002)

18) The association constant of doxorubicin with CT DNA was reported to be $3.3 \times 10^{6} \mathrm{M}^{-1}$ under a similar condition. See: Messori L., Temperini C., Piccioli F., Animati F., Di Bugno C., Pierluigi Orioli P., Bioorg. Med. Chem., 9, 1815-1825 (2001).

19) Wang H.-F., Shen R., Jia L., Wu J.-C., Tang N., Chem. Pharm. Bull., 57, 808-813 (2009).

20) Pang J.-Y., Qin Y., Chen W.-H., Luo G.-A., Jiang Z.-H., Bioorg. Med. Chem., 13, 5835-5840 (2005). 